\title{
Urbanomics in India (Detailed analysis of trends and patterns of urbanization in India)
}

\author{
Rishabh Misra
}

\begin{abstract}
This paper aims at studying trends and patterns of urbanization in India. Paper has been divided into 2 parts, first pre-globalization period which was from 1951 to 1981; their position of urbanization and its trends have been analyzed. Second part deals with post-globalization period which is from 1991 to 2011, their urban status and pattern of urbanization in Indian economy has been analyzed. This was further divided under indicators like social, economic and infrastructure and housing, which give state-variation in urbanization pattern and revealed what is lacking if state has low urbanization rate. In the latter half of the paper urbanization policy "JNNURM" was analyzed and its role in developing urban infrastructure was studied with the help of project allocation and amounts sanctioned to state for urban renewal under this policy. Lastly suitable conclusion and recommendations have been provided in view of status of urbanization in India and problems it faces.
\end{abstract}

\section{Introduction}

It has been noted by World Bank data in $19^{\text {th }}$ century, the urban population represented just $3 \%$ of total world population. At the beginning of $20^{\text {th }}$ century due to industrialization the total share of urban population went up by $13 \%$ and in the second half of the $20^{\text {th }}$ century the growth in urban population showed a drastic increase to $29.1 \%$ due to decolonization of many countries like India, Mauritius, Malaysia became independent nations, governments took self initiative to urbanize the nation, in case of India during partition people who migrated settled in urban areas which increased the number of people staying in towns. Whereas Brazil became a Spanish colony from Portuguese colony, other reasons of industrialization is also partially responsible (BRICS report), these few reasons support our drastic change in level of world urbanization. This continuous increase in world urban population was a sign of development across the globe. In 2005 these numbers went up to $48.7 \%$, nowadays $54 \%$ (UNDP 2014) of the threshold has already achieved the level of urbanization.

It can be pragmatic that while the rural population faintly grows until becoming stable, the urban population constantly grows and exceeds the rural rates. If we take into account the development level of the countries, it can be observed that in $1950,52.1 \%$ of developed countries population was urban; meanwhile $81.9 \%$ of the developing countries were rural. This fact means that more than half $(57.9 \%)$ of the global urban population is living in developed countries, while it only represents $32.1 \%$ of the world population.

The developing countries urban population has continued its growth in the second half of the 20th century. Consequently, in 2005, it represented $42.9 \%$ of these countries' population (227.3million) and $71.6 \%$ of the global urban population. On the other hand, the developed countries urban population growth has been much lower: in 2005, it represented $74.1 \%$ of the total population (around 900 million).

It can be observed that the 1950 European urban population consisted of 276,8 million inhabitants and represented $37.7 \%$ of the global world population, that is, the highest percentage worldwide, followed by the Asian one (32.3\%). In 2005, Asia had the highest world urban population (49.5\%) and Europe had the second highest one (16.6\%), which was similar to the American Latin (13.6\%) and the African one (11.1\%).

\section{How We Define Urbanization In India?}

As per Census of India, 1991

1. All places with a municipality, corporation, cantonment board, or notified town area committee etc.

2. A place with minimum population of 5000:

3. At least $75 \%$ of male main workforce should be engaged in non-agricultural occupations;

4. A density of population should be $400 \mathrm{sq} \mathrm{km}$ per person.

$1^{\text {st }}$ definition of towns is statutory towns, these are the places with urban local bodies like municipalities, and municipal corporations etc fall under statutory town list.

Census Towns: are the towns which are converted from villages to towns when they fulfill the above criterion (2-4).They are like catalyst in the process of urbanization in India. 
Urban agglomerations: is a continuous urban spread constituting a town and its adjoining out growths or physically contagious towns, it could be without out growth also. It should have at least one statutory town and its population shouldn't be less than 20000 (according to census 2001). Example: greater Mumbai UA, Kanpur UA.

Out Growths (OG): is viable unit like village or an enumeration block made of village which clearly identifies its boundaries and location. Places like railway colony, university area, military camps which come near a statutory town outside statutory limits but revenue limits of village contiguous to town (Census of India, 1991). All these above terms are regarded as definition of urbanization in India, places fulfilling the criteria of any above are termed as "Urban" in India.

In the context of Urbanization in India, the present study tries to look at the level of urbanization in India during pre and post-globalization period. Further the study attempts to analyze the spatial variation in urbanization pattern with a focus on social, economic and household indicators during the past decade that is for the period of 2001-2011. Finally the present work tries to establish linkages between them.

\section{Methodology}

To arrive at objectives, certain statistical methods are used. These are:

Social Indicators:

1. Sex ratio which denotes number of female per thousand males living in urban areas is calculated as. Sex ratio $=$ (number of female/ number of male $) * 1000$.

2. Child sex ratio: is number of female over thousand males in an age group of 0-6 is calculated as. CSR= (number of female child/ number male child)*1000.

3. .Literacy rate: is defined as number of people who can read and write excluding the age group of 0-7. Literacy rate $=($ number of literate person/total population $) * 100$.

Economic Indicators:

1. WPR is defined as the sum of main and marginal workers divided by total urban population of the state or region. It is calculated as

(Main work force+ marginal workers)/Total urban population

2. Urban poverty ratio is the ratio of people living in urban areas which fall under state specific poverty line. It is calculated as

(Number of people living below state specific poverty line/total urban population)*100

3. Per capita income is the income of individual living in a state or demographic boundary. It is calculated as (total income of the area/ total population residing).

Percentage of households with basic infrastructure and housing conditions

1. Electricity: is calculated as (number of households with electricity /total number of household) $* 100$.

2. Sanitation: is calculated as (number of households availing sanitation within their premises/total number of households)*100.

3. Bathroom within premises: is calculated as (number of households with bathroom within their premises/total number of households) $* 100$.

4. Banking facilities: is calculated as (number of households availing banking services/total number of households)*100

5. Safe drinking water: is regarded from the sources of treated and untreated tap water, tube well and borings. It is calculated as (sum of all sources of safe drinking water/ total number of household)*100.

6. Closed drains: are the drains to dispose liquid or biochemical waste into water bodies. It is calculated as (number of households using closed drains/total number of households)* $100{ }^{\mathrm{i}}{ }^{\mathrm{i}}$

\section{Principle Component Analysis}

We have taken these indicators into consideration we deeply analyzed and interpreted them to get the results, after this we analyzed PCA (Principle component analysis) on all the indicators to give concrete conclusion to our analysis and interpretation. Principle component analysis is a technique used to emphasis and brings out strong patterns in a data set. It is often used to make data easy to explore and visualize. The technique of principal component analysis enables us to create and use a reduced set of variables, which are called principal factors. A reduced set is much easier to analyze and interpret. To study a data set that results in the estimation of roughly 500 parameters may be difficult, but if we could reduce these to 5 it would certainly make our day. We will show in what follows how to achieve substantial dimension reduction. Weight age of the indicators have been taken by software randomly, no special emphasis is made. Data has been run separately under heads of Social, economic and infrastructure and housing indicators on SPSS. Urban poverty ratio has 
been computed according to Tendulkar methodology and data is of 2004-05 and 2011-12. The main source of data for the values of the indicators is Census of India and planning commission report.

\section{Pre-Globalisation Period (1951-1981)}

According to definition of urbanization by census of India in 1951 all the places with basic facilities like drinking water, schools, electricity, hospitals etc were classified under the status of a "town", under this criteria almost entire population of some states would fall under being urban. High urban growth recorded in 1951 census was recorded also because of massive displacement of population during the partition of the country in 1947 where large number of international migrants migrated to large urban centers.

With the adoption of strict urban definition and its application in census 1961, 803 towns with the population of around 44 million were declassified from urban to rural. This brought fall in urbanization rate of India during 1951-61 to just 2.3\%, beside definitional factors it has been attributed to fall in urban-rural migration. The rate somehow picked up to $3.3 \%$ in 1961-71 due to increase in population in large existing urban centre rather than introduction of new urban centres.

Table1: Number of urban centers in different census years (1951-81)

\begin{tabular}{|l|l|l|l|l|}
\hline State & 1951 & 1961 & 1971 & 1981 \\
\hline Andhra Pradesh & 276 & 211 & 206 & 234 \\
\hline Bihar & 101 & 128 & 163 & 179 \\
\hline Gujarat & 231 & 167 & 198 & 220 \\
\hline Haryana & 56 & 58 & 61 & 77 \\
\hline Himachal Pradesh & 29 & 29 & 35 & 46 \\
\hline Jammu and Kashmir & 23 & 41 & 46 & 56 \\
\hline Karnataka & 283 & 213 & 227 & 250 \\
\hline Kerala & 89 & 73 & 78 & 85 \\
\hline Madhya Pradesh & 194 & 208 & 229 & 303 \\
\hline Maharashtra & 352 & 238 & 253 & 276 \\
\hline Manipur & 1 & 1 & 8 & 31 \\
\hline Meghalaya & 1 & 3 & 3 & 7 \\
\hline Nagaland & 1 & 3 & 3 & 7 \\
\hline Orissa & 39 & 59 & 77 & 103 \\
\hline Punjab & 110 & 106 & 105 & 134 \\
\hline Rajasthan & 221 & 141 & 151 & 195 \\
\hline Sikkim & 1 & 1 & 7 & 8 \\
\hline Tamil Nadu & 263 & 263 & 240 & 245 \\
\hline Uttar Pradesh & 458 & 239 & 283 & 659 \\
\hline West Bengal & 78 & 102 & 112 & 130 \\
\hline Union territories & 10 & 21 & 26 & 45 \\
\hline INDIA & 2818 & 2311 & 2519 & 3301 \\
\hline $\begin{array}{l}\text { Change in number of } \\
\text { towns }\end{array}$ & ----- & -507 & 208 & 782 \\
\hline India, 2001 & & & \\
\hline
\end{tabular}

Source: Census of India, 2001

It must be mentioned that India witnessed accelerating urban growth during seventies not only because of rapid growth of population in existing urban centre's but also because of introduction of new towns which is recorded to 782 according to 1981 census data.

During 1970's the dependence of the work force on agriculture and its allies started diminishing in this decade, the male distribution in this census went down from 67.4 to $63.5 \%$ during 1971-1981. Urbanization rate went from 17.97 in 1961-71 to $19.91 \%$ during 1971-1981 with increase in number of towns from 2519 to 3301 in 1971-81 owing to an absence of sectoral diversification and stagnation in industrial sector during mid sixties.

The decennial growth rate fell from $46.14 \%$ to $36.47 \%$ in 1981-91. Annual exponential growth rate also fell from $3.83 \%$ to $3.09 \%$ in 1981-91. Total number of towns went upto 3378 with 159462.5 thousand people residing in it comprising $23.34 \%$ of total population. Further it is worth mentioning that rate of urbanization slowed down during this period of 1981-91.

The 1991 census has defined urban place as any place with a minimum population of 5,000, 75 per cent of the male population being non-agricultural, population density of at least 400 persons per square $\mathrm{km}$ (or 1,000 persons per square mile) and with a municipality/corporation/ cantonment/notified area.

According to census 1991 there were 4689 total number of towns which comprises of $25.71 \%$ of total population which was termed as "urban".

When compared with the urban population projections made by Experts Committee on Population Projections appointed by the Planning Commission (1989), enumerated urban population and urbanization are on the lower side because as per its medium population projections, 230 million persons or 27.5 per cent of the 
total population were supposed to be urbanites but the actual growth noted was $25.71 \%$. This slackening of urbanization process has posed some serious questions to the scholars studying this phenomenon.

According to Premi (1991) this could be due to a decline in natural growth rate and rate of immigration.

Graph1: Percentage of urban population

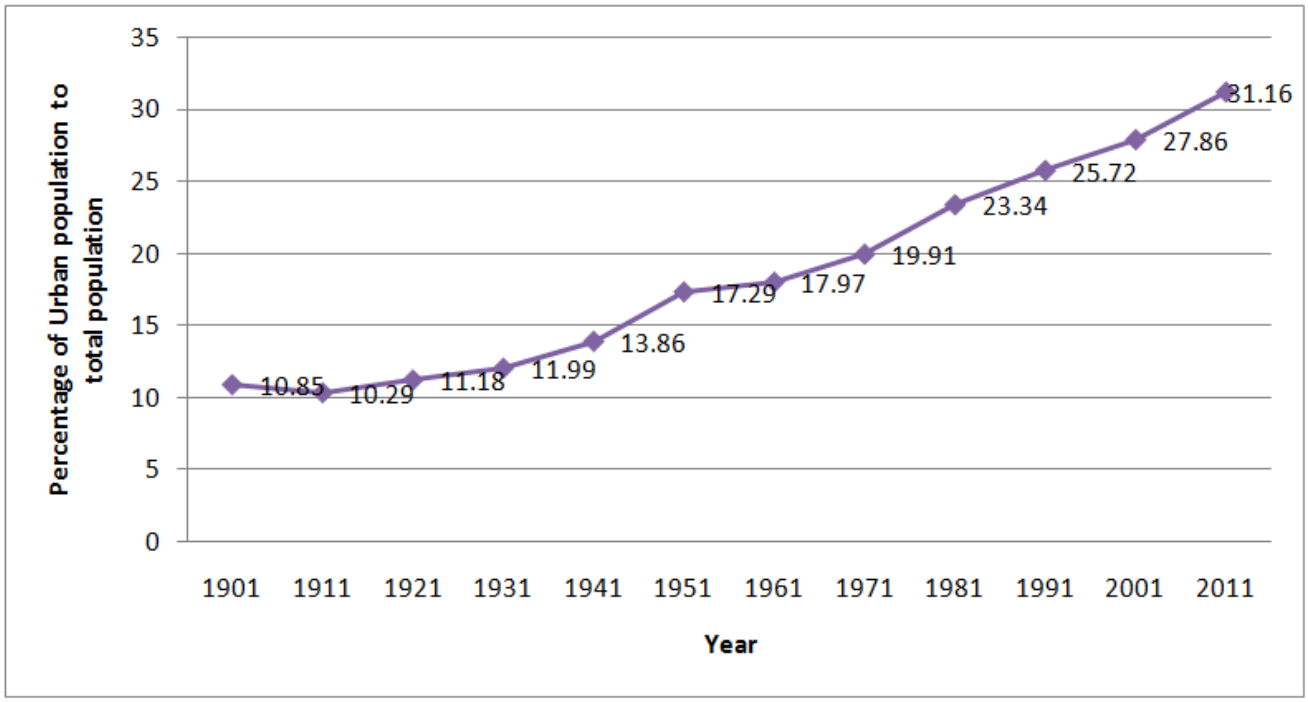

Source: Census of India 2011.

The percentage of urban population has increased 1.5 times from 1951 to 1991 i.e from $17.3 \%$ to $25.73 \%$ with the increase in absolute size of population from 356.9 million to 940 million during the same period, but 1991-2001 was set up has bench mark for urbanization in India because of the newly introduced liberalization policies and exposure of India to the globalised world. The urban growth had far reaching implications not only because of disequilibrium between urban rural developments but also due to accentuate of socioeconomic adjustments.

Table 2: TRENDS OF URBANIZATION IN INDIA SINCE 1961-2011:

\begin{tabular}{|l|l|l|l|}
\hline Census Year & Urban population (millions) & Percentage Urban & Annual exponential urban growth rate \\
\hline 1961 & 78.94 & 17.97 & - \\
\hline 1971 & 109.11 & 19.91 & 3.23 \\
\hline 1981 & 159.46 & 23.34 & 3.79 \\
\hline 1991 & 217.18 & 25.72 & 3.09 \\
\hline 2001 & 286.12 & 27.86 & 2.75 \\
\hline 2011 & 377.10 & 31.16 & 2.76 \\
\hline
\end{tabular}

Source: Census of India 2001

The table shows India had an urban population of about 79 million in 1961 which constituted about $18 \%$ of the total population. The average growth rate of the urban population was $2.32 \%$ during 1951-61 which accelerated up to $3.79 \%$ during 1971-81. This was the highest urban growth since independence. After 1981, the urban growth rate decelerated to 3.09\% during 1981-91 and further declined to 2.75 during 1991-2001. However, the declining growth rate was slightly reversed during 2001-2011. It is worthwhile to note that urban population growth alone cannot speed up urbanization. More importantly, if urbanization has to occur, the urban population growth rate needs to be higher than the rural population growth rate. Thus, it is the urban-rural population growth differential that is critical to the process of urbanization.

\section{POST GLOBALISATION PERIOD (1991-2011)}

During the census period of 1991-2001 introduction of 472 new towns boosted up share of people living in urban areas to $27.78 \%$. These figures might put up a question that how the change from $25.71 \%$ to $27.78 \%$ is a benchmark in the phase of "Urbanizing India", but during this period the concept of census town became more popular and villages with the population of 5000 people were given the status of being "urban". Next step which was taken was increase in the number of urban local bodied like Municipal Corporation, cantonment board, nagar parishad, nagar palika, municipal council, municipality etc were increased. This brought the age of development in India and was a stepping stone for the nation.

\section{COMPONENTS OF URBAN GROWTH:}


The natural increase in population, net rural urban classification, rural-urban migrations are the main components of urban population growth. Since separate information in wake of change in the area and population due to extension of municipal boundaries during the inter-censal period is not available either for total or for migrant population it is difficult to estimate decadal migration to urban area. An assessment to its relative contribution is very important in understanding the dynamics of urban population growth. As there has been no change in the definition of the urban between the 2001 and 2011 censuses, this has contributed significantly to faster urbanization in spite of several metropolitan cities showing a huge decline in their growth rates (Kundu 2011). On the other hand, the contribution of natural increases in urban population growth has declined from a peak of $62 \%$ during 1981-91 to $44 \%$ during 2001-2011. Yet the natural increase added a huge population of about 40 million in the urban areas during 2001-2011, thus rest of urban growth of 66\% is contributed by net rural urban classification of town cities and not only rural-urban migration.

Graph2: Components of Urban population growth (1971-2011)

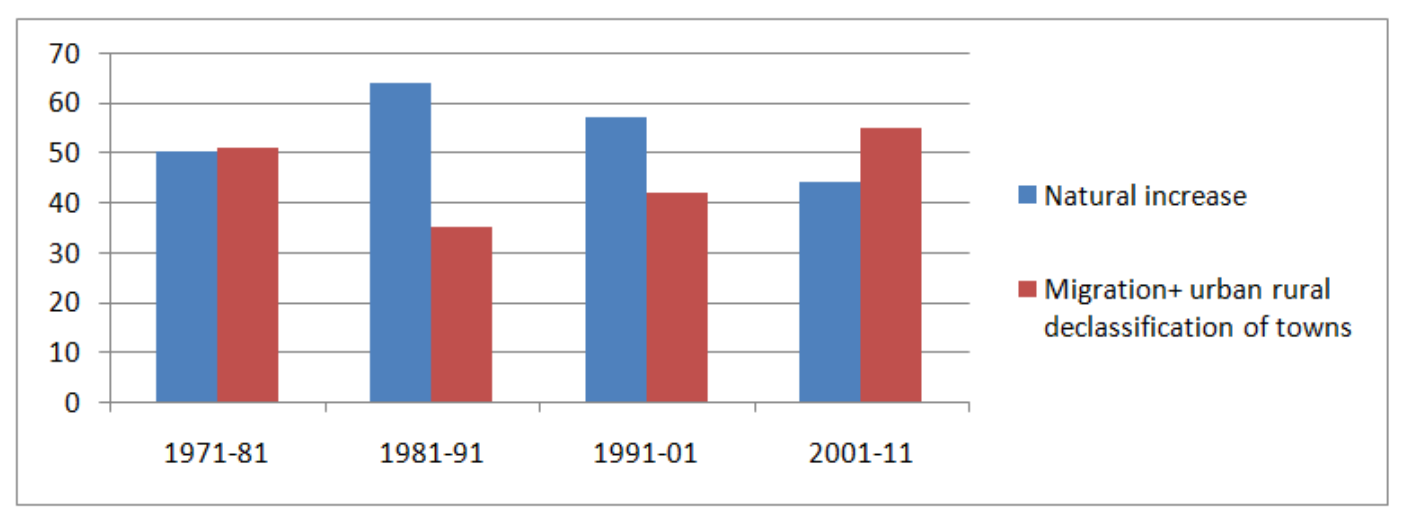

Source: Bhagat, 2011

\section{URBAN AGGLOMERATIONS:}

There were 384 urban agglomerations in 2001 which increased to 474 in 2011 with the inclusion of 137 new UA's and elimination of 35 UA's which were there in 2001 list but not on 2011 data. We saw some shocking results of cities like Vishakhapatnam, Vasai, Ujjain not being included in census 2011 list due to the change in the civic status of the towns, example: Vishakhapatnam has been converted to Greater Vishakhapatnam municipal corporation in 2007, Vasai was changed to Vasai -Virar municipal corporation. (Annexure 1.1)

Census Towns (CT): Introduction of census towns is the main reason behind rapid urbanization in India, there were $\mathbf{1 3 6 2}$ CT's in 2001. In order to accelerate urban growth rate in India number of census towns were increased drastically to 3894 in 2011 . The unexpected increase in the number of census towns (CTs) in the last census has thrust them into the spotlight. Using a hitherto unexploited dataset, it is found that many of the new CTs satisfied the requisite criteria in 2001 itself; mitigating concerns of inflated urbanization. The new CTs account for almost $\mathbf{3 0 \%}$ of the urban growth in last decade, with large inter-state variations.

The changes in the number of CTs between census periods can happen in many ways, e.g., an increase due to reclassification of villages and OGs, and, rarely, STs into CTs,5 and a decrease due to de-notification of existing CTs to villages, re-classification or amalgamation of existing CTs into STs. While the absolute increase of CTs between 2001 and 2011 for the country is 2532, the number of settlements re-classified from village to CT (henceforth new CTs) is 2553 and an additional 141 settlements have been re-classified from OG or ST to CT. Since 48 CTs could not be matched between 2001 and 2011, the actual number might be slightly higher. Concomitantly, 55 CTs have been de-notified to villages and 144 CTs have been recognized as STs or merged with other STs in this period.

Table3: Class wise number of CT's in 2001 and 2011

\begin{tabular}{|l|l|l|}
\hline Class & 2001 & 2011 \\
\hline 1 & 1 & 20 \\
\hline 2 & 11 & 54 \\
\hline 3 & 56 & 593 \\
\hline 4 & 101 & 1148 \\
\hline 5 & 103 & 1713 \\
\hline 6 & 40 & 364 \\
\hline
\end{tabular}

Source: Census of India 2011

The above table states the number of census towns which lie in each category and its increase in number from 2001 to 2011. 
In 2001 number of census towns lying in class 1 category (i.e. population above 1 lakh) was only one but these numbers increased to 20 census towns in 2011 census. This shows increase in the population of the towns has increased considerably. In class 2 (i.e. population between 50000-99999 people) no of towns in 2001 were 11 which went up to 54. We notice considerable changes from class 3 to 6 , this shows that main concentration of building census town was from class 3 to 6. In 2001 there were 56 CT's in class 3 (population lying between 20000-49999) and there were 593 census towns in 2011. Whereas class 4 (population lying between 10000-19999) and class 5 (population lying between 5000-9999) noted 11 times and 16 times growth respectively from 2001 to 2011. Class 6(population lying below 5000 people) had 40 census towns in 2001 which increased to 364 in 2011. The urban population growth of 91 million between 2001 and 2011 is for the first time higher than the absolute rural growth. Using Census dataset we find out that the 2532 new CTs, which were rural areas in 2001, accounted for $26 \%$ to $29.5 \%$ of the urban growth in the last decade.

Statutory Towns

In 2001 there were 3799 statutory towns in India which increased to 4041 in 2011. State of Chhattisgarh recorded highest increase in number of statutory towns from 75 in 2001 to 168 in 2011 . Whereas hilly states like Uttarakhand, Sikkim and Himachal Pradesh didn't get increment in number of census towns in 2011.

Table4: Changes in number of administrative units from 2001-2011.

Source: Census of India 2011

\begin{tabular}{|l|l|l|l|}
\hline S.NO & Admin Units & Numbers in 2001 & Numbers in 2011 \\
\hline 1 & States/ Ut's & 35 & 35 \\
\hline 2 & Districts & 593 & 640 \\
\hline 3 & Tehsil & 5463 & 5924 \\
\hline 4 & Villages & 638588 & 640867 \\
\hline 5 & Towns & 5161 & 7935 \\
\hline
\end{tabular}

Expect the number of states, all administrative units have shown increase in numbers from 2001 to 2011. However census towns increased by $\mathbf{1 8 5 \%}$, whereas statutory towns increased by $\mathbf{6 . 3 7 \%}$. This shows us that number of rural settlements have been granted urban status and are added in census towns

Out Growths: While determining the outgrowth of the town, it was ensured by census that it posses urban features such as infrastructure and basic amenities such as sanitation, electricity, well constructed roads, medical facilities, banks etc then these places are designated as Outgrowth of a town and later constituted in UA's.

In 2011 census there were 981 places which were identified as OG's against 962 in 2001 and majority of 280 OG's lie in class 6 whereas no OG could make to class 1 .

Table5: Size Class of Urban Centres in India (2001 and 2011)

\begin{tabular}{|l|l|l|}
\hline Category & 2001 & 2011 \\
\hline Class 1( more than 1 lakh) & 441 & 498 \\
\hline Class 2 (50000-99999) & 496 & 600 \\
\hline Class 3 (20000-49999) & 1388 & 1911 \\
\hline Class 4 (10000-19999) & 1563 & 2240 \\
\hline Class 5 (5000-9999) & 1041 & 2188 \\
\hline Class 6 (less than 5000) & 232 & 498 \\
\hline Total & 5161 & 7935 \\
\hline
\end{tabular}

Source: Census of India 2001

Urban centres in India have increased considerably in last decade, we witnessed slight increase in class 1 and class 2 towns but considerable change is noticed from class 3 to class 6 , this is basically due to classification of villages to census towns and allocation of new urban centre in these classes.

Table 6: State wise Variation in level of Urbanization

\begin{tabular}{|l|l|l|l|l|}
\hline \multirow{2}{*}{$\begin{array}{l}\text { State } \\
\text { code }\end{array}$} & States/UTs & \multicolumn{2}{l|}{$\%$ of urban population } & AEGR \\
\cline { 3 - 4 } & & 2001 & 2011 & $2001-11$ \\
\hline 0 & INDIA & 27.82 & 31.16 & \\
\hline 1 & Jammu \& Kashmir & 24.81 & 27.21 & 3.05 \\
\hline 2 & Himachal Pradesh & 9.8 & 10.04 & 1.45 \\
\hline 3 & Punjab & 33.92 & 37.49 & 2.29 \\
\hline 4 & Chandigarh & 89.77 & 97.25 & 2.38 \\
\hline 5 & Uttarakhand & 25.67 & 30.55 & 3.5 \\
\hline 6 & Haryana & 28.92 & 34.79 & 3.66 \\
\hline 7 & NCT of Delhi* & 93.18 & 97.5 & 2.36 \\
\hline 8 & Rajasthan & 23.39 & 24.89 & 2.57 \\
\hline 9 & Uttar Pradesh & 20.78 & 22.28 & 2.53 \\
\hline 10 & Bihar & 10.46 & 11.3 & 3.01 \\
\hline
\end{tabular}


Urbanomics in India (Detailed analysis of trends and patterns of urbanization in India)

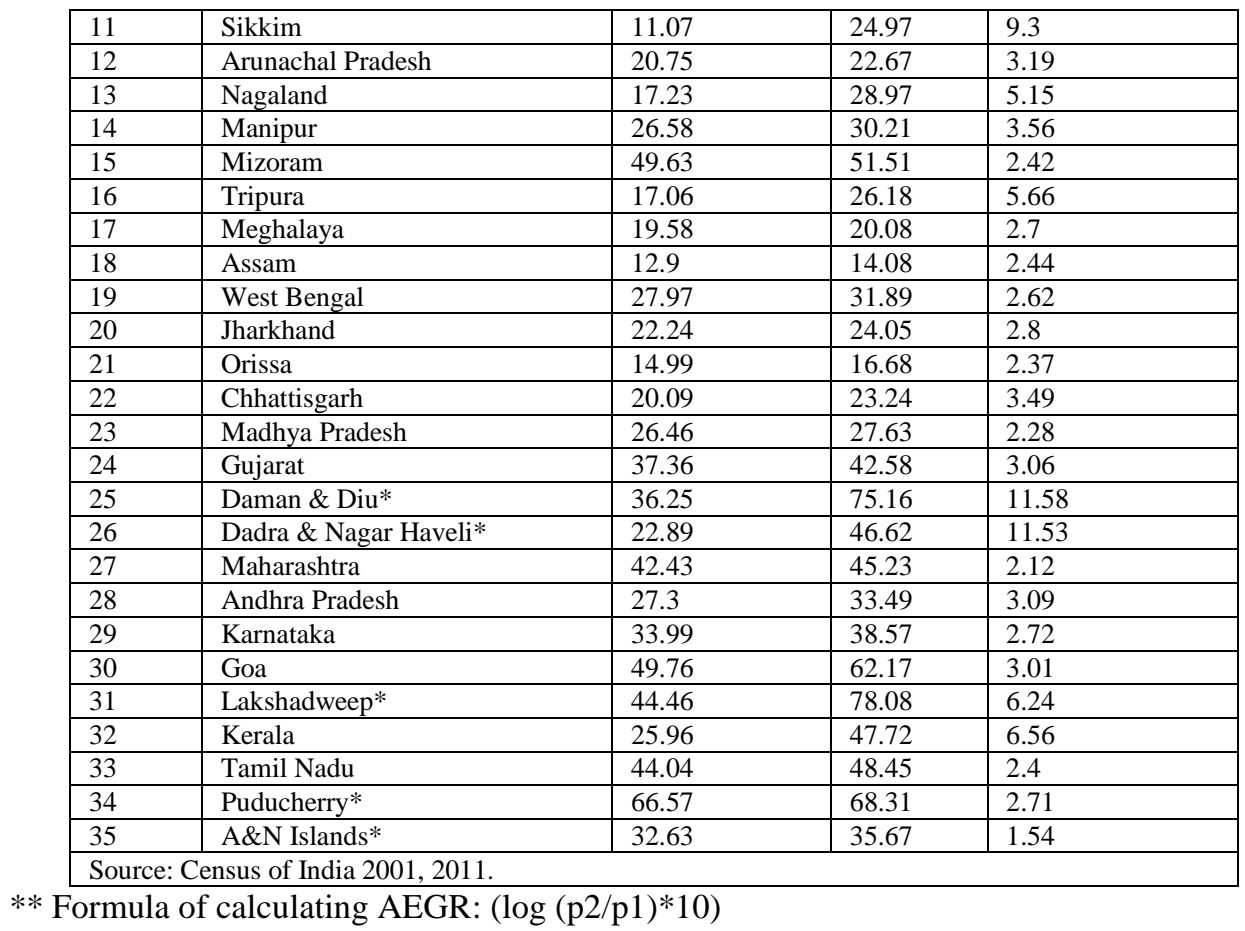

Above table shows us the level of urbanization in Indian states from 2001 to 2011 with annual exponential growth rate over a decade. There was no negative AEGR recorded in this decade. Union territory of Daman and Diu, Dadra Nagar and Haveli recorded highest exponential growth of 11.58 and $11.53 \%$ respectively, followed by three north eastern states of Sikkim, Tripura and Nagaland cumulating to $9.3 \%, 5.66 \%$ and $5.13 \%$ exponential growth over a decade.

If we take major states into consideration then Kerala has registered an impressive growth rate of $6.56 \%$ and its $47.72 \%$ of total population now falls under criterion of being "Urban". Whereas Himachal Pradesh and Andaman and Nicobar islands registered lowest AEGR of 1.45\% and 1.54 respectively and they both lie lowest in the ranking, followed by Bihar where just $11 \%$ of its total population reside in urban areas.

Union territories have imprinted there mark in the process of urbanization in India, though annual exponential growth rate is not very high in these regions but the total population residing in urban areas are way higher than other states. NCT of Delhi has $97.50 \%$ of its total population residing in urban areas, reason for this could be more than 100 census towns were added just in Delhi NCR region, this boosts the urbanization rate and because of this Delhi tops the charts. Delhi is followed by another union territory of Chandigarh where $97.25 \%$ of population is urbanized.

If we take only states into consideration for urbanization, Tamil Nadu tops the chart with $48.45 \%$ of population residing in urban regions with AEGR of 2.4\% from 2001 to 2011. Tamil Nadu is followed by its neighboring state of Kerala which has recorded increase of $22 \%$ population from 2001 to 2011 in urban areas, statistics calculates it to be $47.72 \%$ of Kerala's total population is now urbanized. Reason behind such a rapid urbanization in Kerala is considerable increase in number of census towns added in 2011 census, in 2001 there were 99 census towns in Kerala which increased to 461 in 2011, increase in 362 census towns brought this change in rate of urbanization. Goa has shown a magnificent performance in urbanization with $62 \%$ of its population residing at urban centre's.

Himachal Pradesh is the least urbanized state of India with just $10.4 \%$ population residing in urban areas and its annual exponential growth is also recorded to be lowest at $1.45 \%$. The reason behind its on low rate of urbanization is that the state is not able to fulfill urban criterion at maximum places, like population density of 400 people per sq kilometer is required but the population density of whole state is 123 people per sq kilometer which is way lesser than the desired qualification for being urban and due to terrain they fail to qualify.

Bihar follows up Himachal Pradesh in being another least urbanized state with 11.3 of total population living in Urban areas but annual exponential growth rate is 3.01 which is good sign of growth, this could be due to implementation of dynamic government policies introduced in second half of the decade which gave little lift to urbanization (Bihar Planning Commission Report 2010).

\section{QUALITY OF LIFE IN URBAN INDIA}



follows:

To analyze the quality of life in urban India we have taken four parameters in this paper, they are as

SOCIAL INDICATORS: Includes sex ratio, child sex ratio and literacy rate as indicators in this paper.

Taking sex ratio into consideration it was state of Kerala on the top in 2001 with sex ratio of 1058 female over 1000 males, states consistency continued in 2011 also with increase in ratio to 1084 females over 1000 males. Chhattisgarh the newly formed state in 2001 held second position in 2001 with 989 females over 1000 males, but due to poor performance in other indicators the sex ratio was noted to be 991 females over 1000 males in 2011 census and it was replaced by the state of Tamil Nadu with 996 females over 1000 males. Due to gender biasness in states like Haryana and Punjab where gender inequality prevails makes these states lie low on the list with 871 and 876 females over 1000 males respectively in 2001 and stats went up to 879 for Haryana in 2011 and improving the situation for Punjab as ratio increased to 896 females over 1000 males, it's been noted that these two states have low child sex ratio also which is not allowing them to coop up with the pace of other states.

Graph 3: State wise sex ratio 2001 and 2011

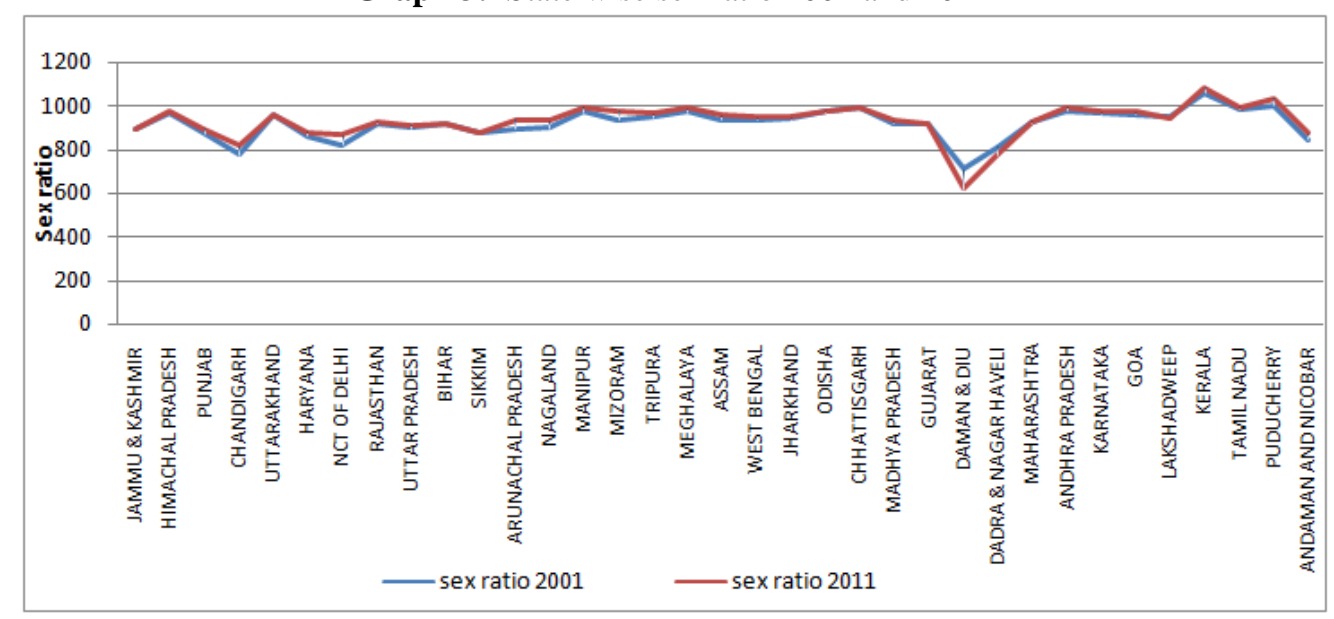

Source: Census of India 2011

Kerala is not only best in terms of sex ratio but also in literacy attributes, Kerala had urban literacy rate of $93 \%$ in 2001 and went up to $95 \%$ in 2011 placing the state on second position after Mizoram. When we talk about urban literacy rate it's the north eastern state of India "Mizoram" topping the charts in both 2001 and 2011 with $96 \%$ and $98 \%$ respectively. It's been analyzed that northern states of India have comparatively low literacy rate as compared to southern states, states like Bihar, Jammu and Kashmir and Uttar Pradesh lie at the bottom of rank tables of with $72 \%, 72 \%$ and $70 \%$ in 2001 which increased to $79 \%$, 78\% 77\% respectively in 2011 , this increase in literacy rate could get a hike in there rankings as other states grew comparatively more with better existing base.

If a state has good Child sex ratio then its other social indicators has a solid base to grow. North eastern states like Mizoram, Manipur, Nagaland have been doing consistently well in term of sex ratio and literacy rate in spite of demographic and low availability of resources these states hold strong position. This could be said as they have very high child sex ratio in 2001 and 2011 so there literacy rate and sex ratio is also good. It was Arunachal Pradesh 980 females over 1000 males in 2001 followed by its neighboring state of Meghalaya with 969 females over 1000 males.

The CSR in India has declined from 927 girls per 1000 boys in 2001 to 918 according to Census 2011. Wide variations are seen in ratios across different regions of the country. Overall, the CSR remains adverse in 21 states and Union Territories, the fall ranging from 3 to 79 points. On the other hand, 11 states and two union territories have registered an increase in CSR during the last decade. Changes in CSR at the district level are more pronounced. Of the total 640 districts in the country, 429 districts have experienced decline in CSR. Gender biased sex selection is a discriminatory practice that is a result of a complex web of factors: deep-seated patriarchal mindsets that lead families to value sons over daughters, the need for small families, but with sons, and commercialization and misuse of medical technology that enables illegal sex selection.( reference: mapping the adverse sex ratio in India census 2011).

It's a matter of concern for Punjab and Haryana which has consistently low child sex ratio, this is the reason for their low literacy rate and sex ratio though Punjab has gained 19 points in 2011 from 876 to 895 in 2011 but Haryana has gained from 871 in 2001 to 879 in 2011, the reasons for the same are explained above. 


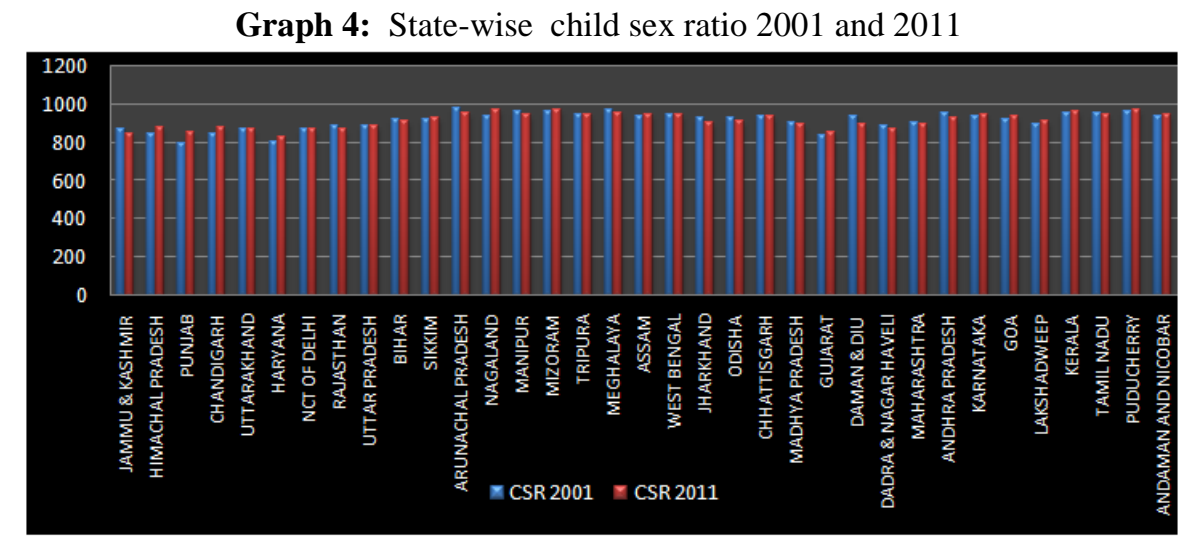

Source: Census of India 2001 and 2011

When we compile all three indicators we have witnessed that North eastern states have performed considerably well especially Mizoram, Meghalaya and Tripura. These states have recorded consistent increase in literacy rate and sex ratio, child sex ratio have fell but in comparison to other developed states it was ignorable as sex ratio increased indicating movement of female from child sex ratio to sex ratio prospect. If we compare demographic zones southern states of India have a hand over Northern states in prospect of sex ratio, literacy rate and child sex ratio because all these three indicators are complementary to each other if one is good then other responses to be well that is why south Indian states have all three indicators complementing each other in comparison to irregular trends in northern states. (e.g): Kerala has sex ratio of 1084, child sex ratio of 962 and literacy rate of 95\% where as north Indian state like Punjab, Uttar Pradesh has low sex ratio, literacy rate and child sex ratio, this proves our statement of all indicators complementing each other.

While calculating PCA, it reveals that higher the index number better the conditions of the states e.g.: Kerala has a variation of 2.03 highest among all states, so this reveals that according to these three indicators Kerala has performed best and vice versa with Jammu and Kashmir. As mentioned in above discussions due to low sex ratio and child sex ratio Punjab and Haryana shows insignificant values in PCA to -1.25 and -1.561 respectively (Graph: Social Indicator).

Graph 5: State wise Variation in Social Index Values, 2011

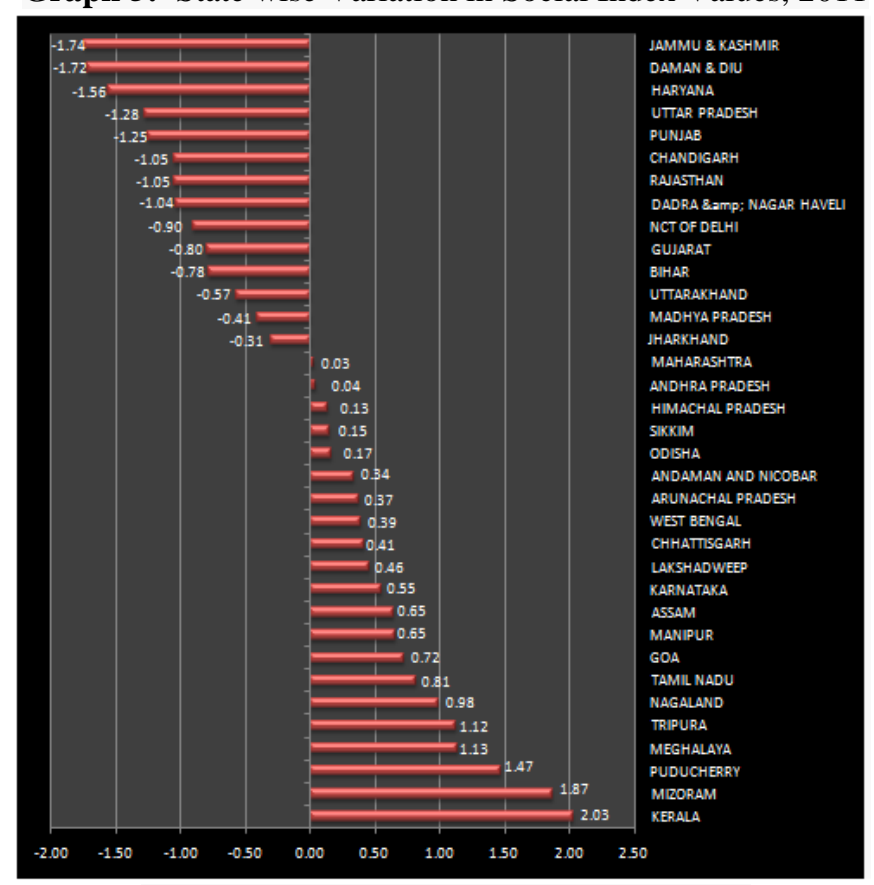

Source: Calculated from Census Data 2011

ECONOMIC INDICATORS: includes parameters like worker participatory rate, urban poverty ratio and per capita income.

Sikkim was the highest contributor in 2001 for WPR with $42 \%$ but the rate fell down to $28 \%$ in 2011 because there was increase in urbanization level of 13 points, this means that urban population increased but 
there was diminishing increase in the workforce so this bought down the graph for Sikkim. Maharashtra replaced Sikkim in 2011 on the top with $42 \%$ of total workforce from $37 \%$ in 2001 . Arunachal Pradesh replaces its neighboring state of Manipur which had 41\% WPR in 2001 and fell to 38\% in 2011, whereas Arunachal Pradesh hiked up to $41 \%$ in 2011 from $37 \%$ in 2001. In 2001 Bihar and Jharkhand both had 29\% WPR which increased to $31 \%$ and $36 \%$ respectively as the number of workers increased with the pace of urbanization in these states. Bihar and Jharkhand were replaced by Kerala and Sikkim with 28\% WPR in 2011. It is been observed that newly formed states of Uttarakhand and Jharkhand which lied low on the table in 2001 showed great improvement in 2011 after being separated from their parent state. They both grew with 6 and 7 points respectively over a decade.

As urban population increased in India urban poverty went down accordingly, Bihar ranked $1^{\text {st }}$ in 2001 with $42 \%$ of its urban population falling under poverty line but it showed improvement in 2011 where just $31 \%$ of total population lie below poverty line, though it ranked second as compared to other states but fall of 11 points is a good sign of growth in Bihar. Manipur had highest population falling under urban poverty line of $32 \%$ in 2011 but it also experienced fall from 35\% in 2001. The state which showed highest fall in urban population is Orissa it ranked $2^{\text {nd }}$ in 2001 with $37 \%$ of its population falling under poverty line and in 2011 it is left with just $17 \%$ due to significant increase in per capita income. In 2001 there were just $4.6 \%$ people falling under poverty line in Himachal Pradesh and 4.3\% in 2011, the reason for such a low percentage falling under poverty line is that there are very few people living in urban areas in this state so the proportion of poor is also low according to low population. Goa had shown significant fall in urban poverty ratio from $22 \%$ in 2001 to $4.5 \%$ in 2011 this is due to $50 \%$ increase in the per capita income of people.

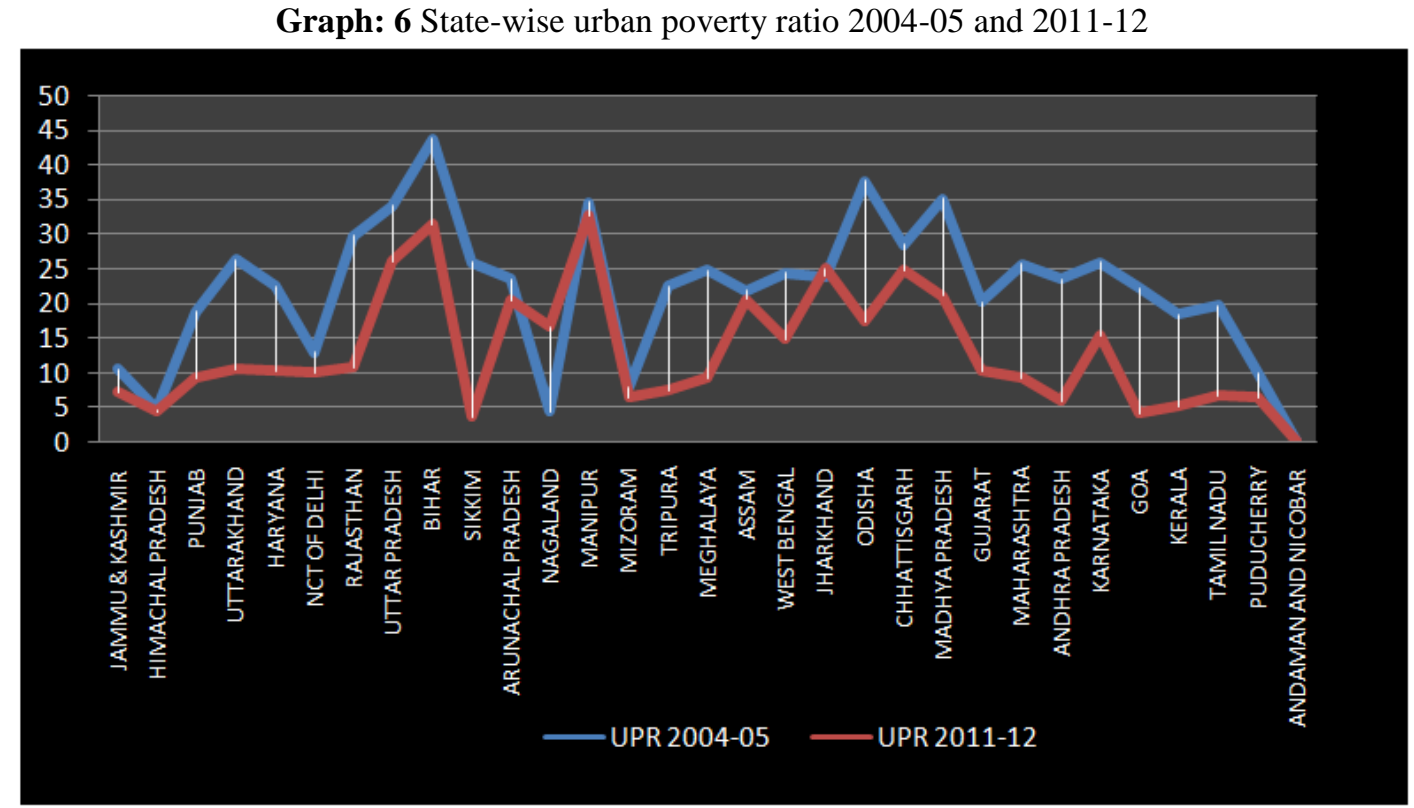

Planning Commission Report on poverty 2011 (Tendulkar methodology) When we glance at responsiveness in per capita income, it's Goa which had been the state with higher per capita income in 2001 with Rs 48582 and Rs 96705 in 2011 showing 50\% increase in per capita income. In 2011 NCT of Delhi topped the charts with Rs 100257 and in 2001 it was just Rs42378 this drastic change is due to expansion of NCR region from board to permanent planning board and expansion in its boundaries so this brought industrial setup within the boundaries so this brought increase in revenue. Bihar has been the state with lowest per capita income in 2001 and 2011 with Rs 8533 and Rs12122 in respective years. Other low performers are Uttar Pradesh and Jharkhand very high population and low workforce is the reason for their low ranking.

We have observed from data that like social indicators economic indicators are also dependent on each other for growth if a state has low urban poverty ratio this tends them to have better workforce and per capita income.

Analyzing Economic Indicators we conclude that Goa has the best performance in computation of all three indicators in PCA with variation of 2.18 which shows strong bond among economic indicators and it has also been noticed that urban poverty ratio has negative relationship with per capita income and wpr. Uttar Pradesh and Bihar have shown insignificant value on PCA of -1.69 and -2.19 respectively which reveals very poor condition of the state with these indicators.(Graph: Economic Indicator). Urban poverty ratio has been calculated according to Tendulkar methodology for year 2004-05 and 2011-12. 


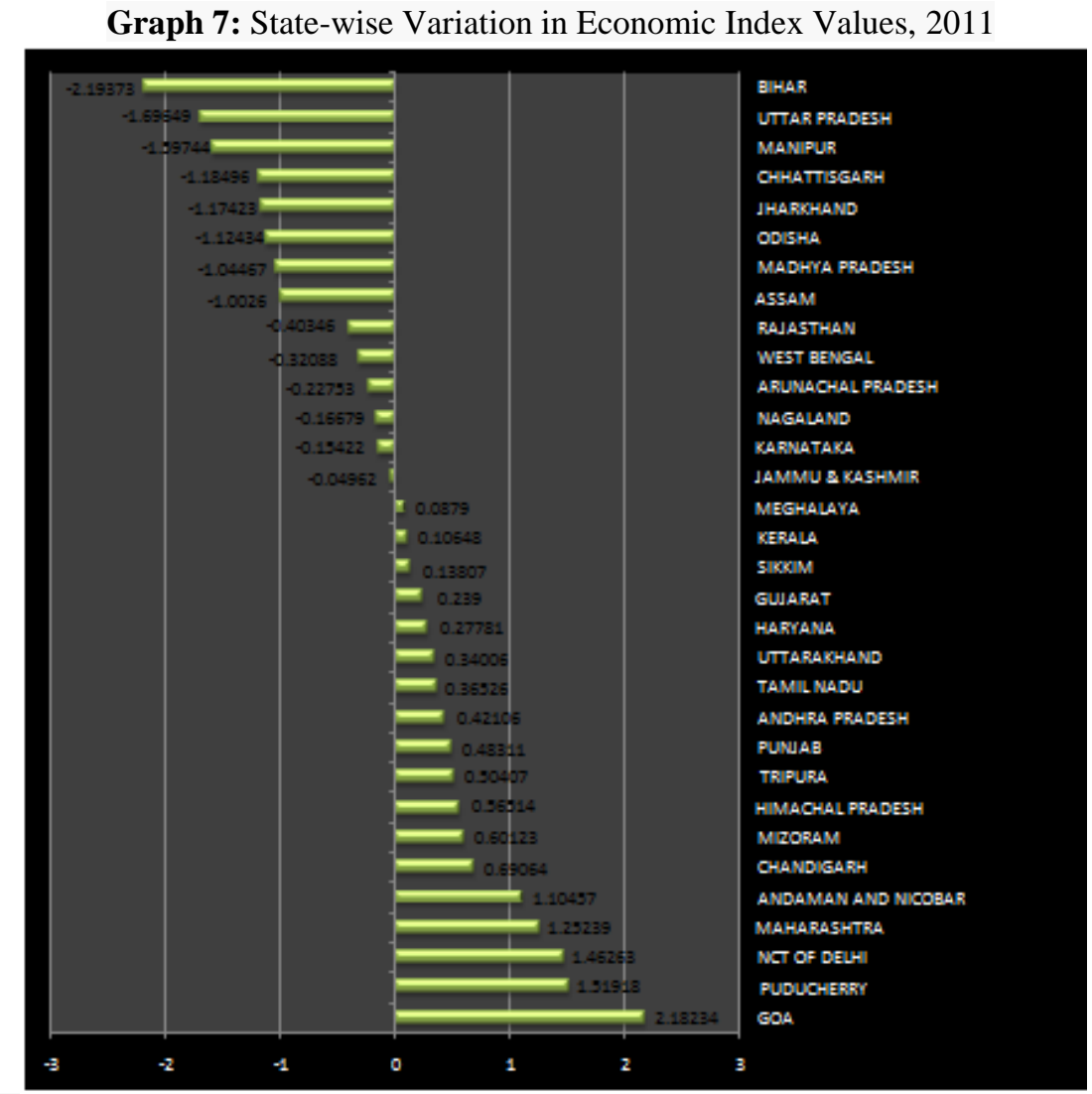

Source: Calculated from Census Data 2011

Infrastructure \& Household Indicators: includes basic amenities and services required for urbanization, indicators like percentage household with electricity, with and without sanitation, with bathroom within the premises, number of household availing banking services, household with safe drinking water, all types of drainage system are taken into consideration.

Lakshadweep hailed to have electricity in each and every household of their urban region in 2001 and 99.66 in 2011, this extraordinary statistics are due to low population and area which eases the connectivity. When we consider states then Jammu and Kashmir had 98\% of households with electricity in 2001 and 98.04 in 2011. In 2011 NCT of Delhi have 99\% household with electricity but a irregular supply. States like Bihar, UP, Orissa have low percentage with electricity due to very high population and number of households. Bihar had lowest of 59\% household in 2001 which increased to 67\% in 2011. Orissa which lied just above Bihar in 2001 with $74 \%$ household with electricity has gone upto $84 \%$ in 2011, but Uttar Pradesh only took a step of $1 \%$ over a decade calculating from $80 \%$ household to $81 \%$ with electricity, this shows that nothing has been done in Uttar Pradesh to improve electricity services efficient productive industrial places like Kanpur which used to be known as "Manchester of India" suffers 4 to 6 hours of power cut which results in steep fall in the productivity and output. Reference( timesofindia.indiatimes.com). Number of people availing latrine services is highest in the state of Mizoram where 98\% household had latrine within premises and 2\% didn't had, in 2011 numbers went up to $99 \%$ with sanitation so we can expect till now this state to have sanitation services in every household. Tripura had $97 \%$ of households with sanitation service in 2001 and $98 \%$ in 2011.Its been analyzed that all north eastern states have good sanitation facilities for their citizens. Maharashtra the state with one of the highest urbanization rate had 58\% households with latrine and 71\% in 2011, this is the thing to attract attention of Maharashtra government to implement the sanitation policies but this was basically due to large slum population in Maharashtra which don't have their private latrine services. Chhattisgarh had been the lowest ranked state in terms of sanitation facilities in both census, there were 53\% households with latrine in 2001 and $60 \%$ in 2011 . We have noticed increase in number of latrine in these low ranked states but still dynamic progress is required if we have a vision of urbanized India in true manner because it is a matter of concern after seeing high urbanized states like Maharashtra and Tamil Nadu with such a low percentage.

Safe drinking water includes water from treated tap water, untreated tap water, hand pump and tube well. Nation claims $91 \%$ household with safe drinking water facilities still $9 \%$ of urban population still have to depend on other sources for drinking water. India's huge and growing population is putting a severe strain on all 
of the country's natural resources. Most water sources are contaminated by sewage and agricultural runoff. India has made progress in the supply of safe water to its people, but gross disparity in coverage exists across the country. Although access to drinking water has improved, the World Bank estimates that $21 \%$ of communicable diseases in India are related to unsafe water. In India, diarrhea alone causes more than 1,600 deaths daily-the same as if eight 200-person jumbo-jets crashed to the ground each day (reference: water.org).

According to census data union territory of Chandigarh have provided $99 \%$ of its households with safe drinking water in 2001 and 100\% households in 2011, followed by another union territory of Daman and Diu with $99 \%$ in both census years. It is not very tough task for union territories to provide large number of households with safe drinking water facilities comparison to large states with very high population. Punjab ranks high among all states with $99 \%$ of households in urban area with safe drinking water facilities in both census years of 2001 and 2011, other northern states like UP, Uttarakhand and Delhi dominates the table as major rivers of India flow from the lap of Himalayas which is located in northern region of India so high flow and availability of flowing water gives a hand of benefit for northern states. Union territory of Lakshadweep had only $5 \%$ of its households with safe drinking water in 2001, numbers increased to $20 \%$ in 2011 . Kerala one of the most urbanized and developed state of India provided $42 \%$ of its household with safe drinking water in 2001 and numbers became even worse in 2011 with just $39 \%$ of households with the facility of safe drinking water due to high increase in number of towns and difference in reported town data in 2001 and 2011. Other low ranked states are north eastern states as they have to depend on rivers and other natural sources for water and due to very low temperature in winter's lakes, ponds, rivers freeze so this pushes them with $50 \%$ of urban aggregate urban population with safe drinking water.

Availability of bathroom within the premises has improved in urban India over a decade. Lakshadweep had $85 \%$ of household with bathroom in their premises in 2001 which has risen to $97 \%$ in 2011 showing optimistic change of 12 points, states like low urbanized states like Uttarakhand and Himachal Pradesh has shown great improvement by making their remarkable improvement in provision of bathroom facilities within premises. Uttarakhand and Himachal had $75 \%$ of households with bathrooms within their premises in 2001 and $88 \%$ and $90 \%$ respectively in 2011 . On one hand Sikkim has $90 \%$ of its households with this facility on the other hand its neighboring state Manipur lies way back with just 16\% in 2001, but data in 2011 is a silver lining for this beautiful state where $49 \%$ of households now avail bathrooms within their premises with considerable increase of 33 points. We once again we see Bihar at the bottom of the charts where there were just $43 \%$ of household with bathroom facilities in 2001 and stats went up by just 3 points to $46 \%$ in 2011 showing negligible growth just like its urbanization rate. Banking facilities are the basic need for urbanized India as people are now more interested to keep their money in market flow and get increment over the amount by circulating it in market rather than keeping lump sum in savings. Least urbanized state of India Himachal Pradesh tops the chart in 2011 with $89 \%$ of its households availing banking services where in 2001 there were just $75 \%$ households with it. Goa has also shown consistent growth as it had 77\% in 2001 and 88\% with banking services in 2011. Other states have also shown gradual increase in numbers, but Tamil Nadu has shown significant growth from $30 \%$ household in 2001 with banking services and 76\% in 2011 the main increase was witnessed after 2004 especially nearby region of Siva Ganga, according to economic times due to finance minister at that time who concentrated on banking development in this region as apart from opening ATMs and branches, these banks hold credit camps with huge promotional spending as they fawn over the country's financial boss. It is another matter that lending through these camps has turned out to be the main source for NPAs. But few bankers will admit this publicly, (source: http://articles.economictimes.indiatimes.com/). $\quad$ No of people availing banking services has increased considerably over a decade we can say this due to effective policies introduced by government like "Jhan dhan Yojna", attractive insurance policies and revised policies by RBI. Numbers are expected to have increased till now as there is boom of E-banking user.

According to urban point of view drainage system is disposal of liquid waste in the water bodies, states in India have closed drainage system and open drainage system in which Chandigarh and Gujarat are best with $77 \%$ and $57 \%$ respectively in 2001 and in 2011 they had $87 \%$ and $69 \%$ closed drainage facility. States like Tripura Nagaland Manipur have been performing very poorly continuously in both census years with average of 6\% in 2001 and 7\% in 2011, Lakshadweep had no drainage facility in 2001 and they hiked upto 15\% in 2011.

When we discuss about open drainage in $200166 \%$ of household in Uttar Pradesh used open drainage system whereas in 2011 slight improvement was seen as $61 \%$ used open drainage, while in Andaman and Nicobar Islands 65\% used open drainage in 2001 and hiked upto 74\% in 2011. Among states Kerala and Gujarat has least number of users of open drainage with 16 and $19 \%$ respectively in 2001 and Kerala went upto $21 \%$ in 2011 whereas Gujarat showed improvement by falling to 16\%. In 2001 Lakshadweep had 100\% no drainage and $74 \%$ in 2011 with no drainage, on the other hand Kerala had $69 \%$ of household in 2001 and $47 \%$ in 2011 using no drainage. Delhi, Uttar Pradesh and Sikkim had least households with no drainage in 2001 9\%, 8\%, 6\% respectively in 2001, in 2011 Chandigarh had least households with no drainage with $4 \%$ and Delhi also fell to $4 \%$ showing development in drainage facilities. 
Housing: includes condition of houses according to its characterization under good, livable and dilapated and number of households in slums of each states are analyzed.

Goa is the state which has recorded highest growth in number of good housing conditions from 2001 to 2011 by 39 points. In $200146 \%$ had good conditioned houses which increased to 85\% in 2011. Lakshadweep with highest share of $85 \%$ (good houses) in 2001 declined to $73 \%$ in 2011 replaced by Jammu and Kashmir from $57 \%$ to $80 \%$ in 2011. Maharashtra had lowest share of $33 \%$ in 2001 which increased to $79 \%$ in 2011 due to new policies for housing improved the stats for nation as a whole but in 2011 Maharashtra was replaced by Jharkhand and Sikkim where just 52\%and $50 \%$ people lived in good housing conditions.

Livable conditions are the satisfactory condition in which a family can live and get a shelter with needful things. In 2001 Maharashtra had 55\% of households which were livable and in 2011 it fell down to 25\% due to rise in good conditioned houses. In 2011 Orissa have largest share of livable houses of $43 \%$ and followed by Bihar with 40\%. In 2001 Lakshadweep had 12\% livable houses and increased to 14\% in 2011. Maharashtra tops the chart with $11 \%$ in 2001 for dilapated housing condition and in 2011 it went down to $2 \%$ due to same reason of drastic increment of good housing conditions. In 2011 Bihar replaced Maharashtra on the first place with 7\% households with dilapated houses followed by West Bengal with same percentage. In 2001 Uttar Pradesh had just $1 \%$ of dilapated houses, which increased to $4 \%$ in 2011. Dadra Nagar and Haveli had least number of dilapated houses in 2011 with $0.22 \%$ and in 2001 they had $11 \%$ of households with dilapated houses showing considerable fall in numbers.

Taking number of slum households in urban areas we can comment that Maharashtra which had 27\% slum household population in 2001 decreased to 22.7\% in 2011. Andhra Pradesh replaced Maharashtra in 2011 with $35.7 \%$ of slum households in urban population against $25 \%$ in 2001 . North eastern states and Himachal Pradesh didn't record any slums in 2001, and in 2011 it was just Manipur which did not record any slums, others which had no slums in 2001 recorded slight increase in slum households.

While running PCA we took indicators which give us positive and strong output for states development on the basis of infrastructure and housing. Lakshadweep and Himachal Pradesh are the best performer in Infrastructure and Housing indicators this is because of the countable number of urban centre's in the state so the provision of basic amenities is easier than other states with large number of urban centre's, so this enables them to emerge with significant PCA values.(Graph: Infrastructure and Housing).

Graph 8: State-wise Variation in housing conditions and basic Infrastructure Index values 2011

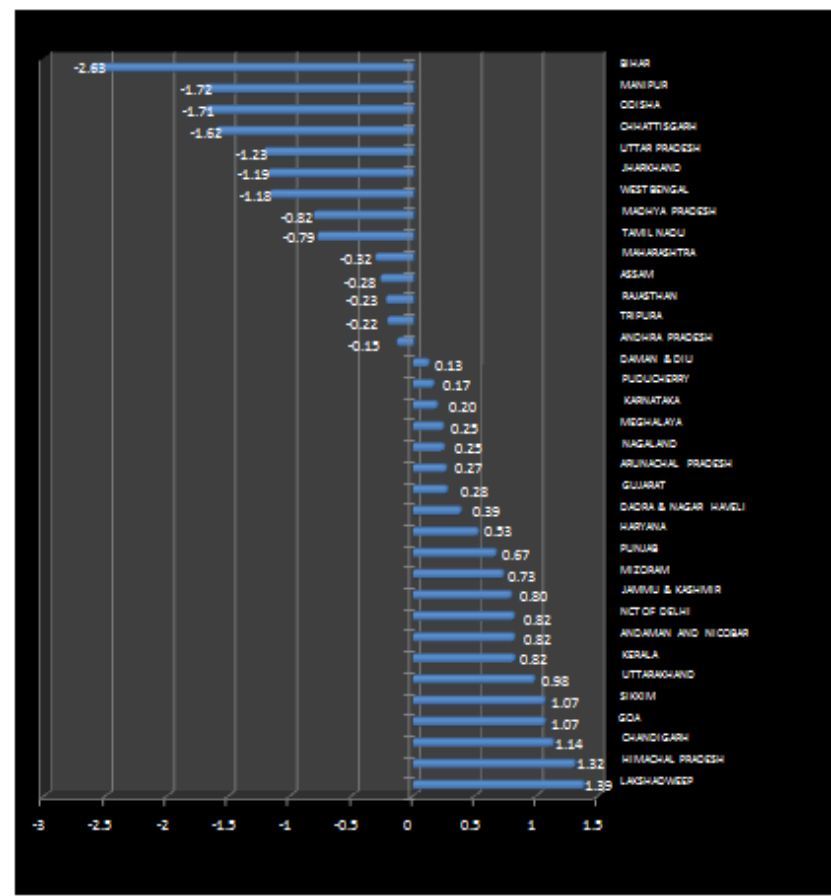

Source: Calculated from Census Data 2011 


\section{Impact Of Jawaharlal Nehru Urban Renewable Mission In Building Urban Infrastructure}

\section{The Mission:}

The aim is to encourage reforms and fast track planned development of identified cities. Focus is to be on efficiency in urban infrastructure and service delivery mechanisms, community participation, and accountability of ULBs/ Para stately agencies towards citizens.

Objectives of the Mission:

(1) The objectives of the JNNURM are to ensure that the following are achieved in the urban sector;

- Focused attention to integrated development of infrastructure services in cities covered under the Mission;

- Establishment of linkages between asset-creation and asset-management through a slew of reforms for long-term project sustainability;.

- Ensuring adequate funds to meet the deficiencies in urban infrastructural services;.

- Planned development of identified cities including peri-urban areas, outgrowths and urban corridors leading to dispersed urbanisation;

- Scale-up delivery of civic amenities and provision of utilities with emphasis on universal access to the urban poor;

- Special focus on urban renewal programme for the old city areas to reduce congestion;

- Provision of basic services to the urban poor including security of tenure at affordable prices, improved housing, water supply and sanitation, and ensuring delivery of other existing universal services of the government for education, health and social security.

Strategy of the Mission:

- Preparing City Development Plan: Every city will be expected to formulate a City Development Plan (CDP) indicating policies, programmes and strategies, and financing plans.

- Preparing Projects: The CDP would facilitate identification of projects. The Urban Local Bodies (ULBs) / parastatal agencies will be required to prepare Detailed Project Reports (DPRs) for undertaking projects in the identified spheres. It is essential that projects are planned in a manner that optimizes the life-cycle cost of projects. The life-cycle cost of a project would cover the capital outlays and the attendant O\&M costs to ensure that assets are in good working condition. A revolving fund would be created to meet the O\&M requirements of assets created, over the planning horizon. In order to seek JNNURM assistance, projects would need to be developed in a manner that would ensure and demonstrate optimization of the life-cycle costs over the planning horizon of the project.

- Release and Leveraging of Funds: It is expected that the JNNURM assistance would serve to catalyse the flow of investment into the urban infrastructure sector across the country. Funds from the Central and State Government will flow directly to the nodal agency designated by the State, as grants-in-aid. The funds for identified projects across cities would be disbursed to the ULB/Parastatal agency through the designated State Level Nodal Agency (SLNA) as soft loan or grant-cum-loan or grant. The SLNA / ULBs in turn would leverage additional resources from other sources.

- Incorporating Private Sector Efficiencies: In order to optimize the life-cycle costs over the planning horizon, private sector efficiencies can be inducted in development, management, implementation and financing of projects, through Public Private Partnership (PPP) arrangements.

(source: www.jnnurm.nic.in).

Graph 9:: State wise comparison of projects sanctioned vs completed

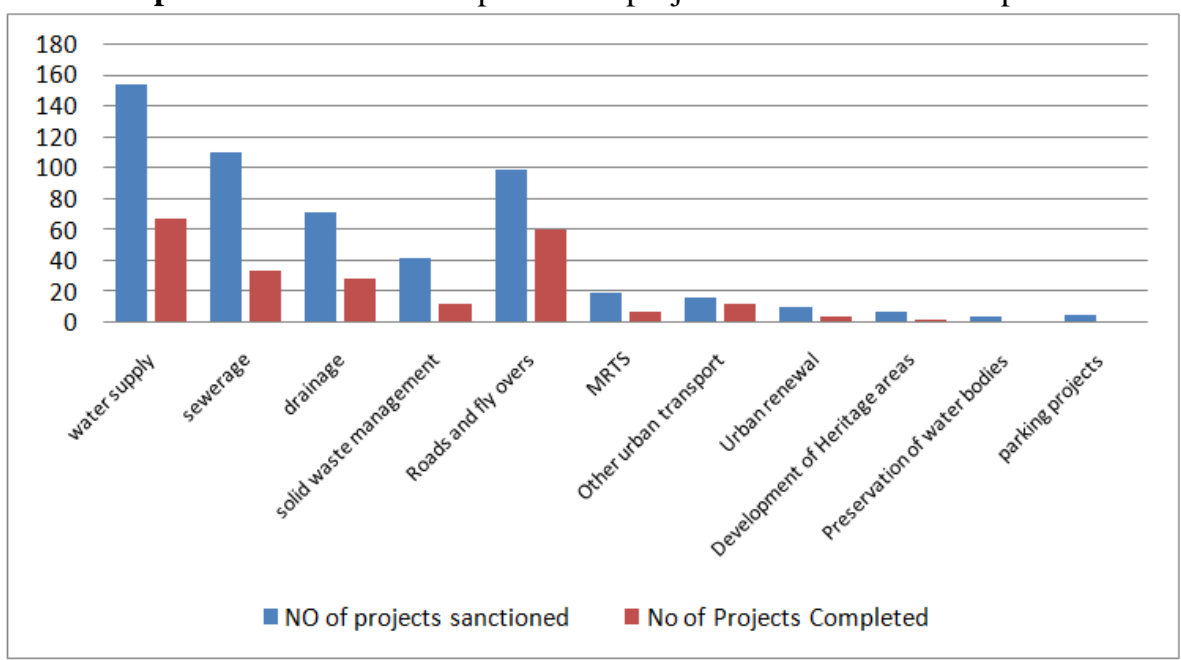

State-Wise Sanctioned Amount Under Jnnurm: 
States were sanctioned with amounts for their urban renewable program, by analyzing the share of a state in Jnnurm sanction amount; we will try to conclude the role of this policy in the process of urbanization.

By analyzing the data and combining UIG and UIDSSMT amounts we get to see that states were given grants according to their size not necessity, states with high population were given preference whereas small states had to be satisfied with small amount. Maharashtra was sanctioned way higher grants than any other state, total of Rs 1802051 lakhs were given to Maharashtra with a share of $19.65 \%$ share of total Jnnurm allocated amount, when we look at its infrastructural indicators and results of PCA we get value to 0.266 which is an significant value but not as significant to the share it holds for urban renewal the pace has been slow and amount has not been properly used, if there was proper allocation then the PCA values would have been way significant according to optimal utilization. The fact which is revealed from the study is the behavior in the pattern of urbanization in Tamil Nadu, is that under Jnnurm it holds the second highest share of $8.49 \%$ and the total amount of Rs7782582.3 lakhs but its infrastructural indicators on PCA gives us the result of -0.449 which is c because the projects which were sanctioned under JNNURM for state mainly concentrated at specific urban centers they were not equally distributed.. It has been noticed that states smaller in size and population have been allocated with low share, no state from north east and union territories except Delhi constitute more than $1 \%$ share which clearly states that money has been allocated according to the size of the state. (Refer annexure 1.2).

Graph 10: State wise sanctioned and completed projects

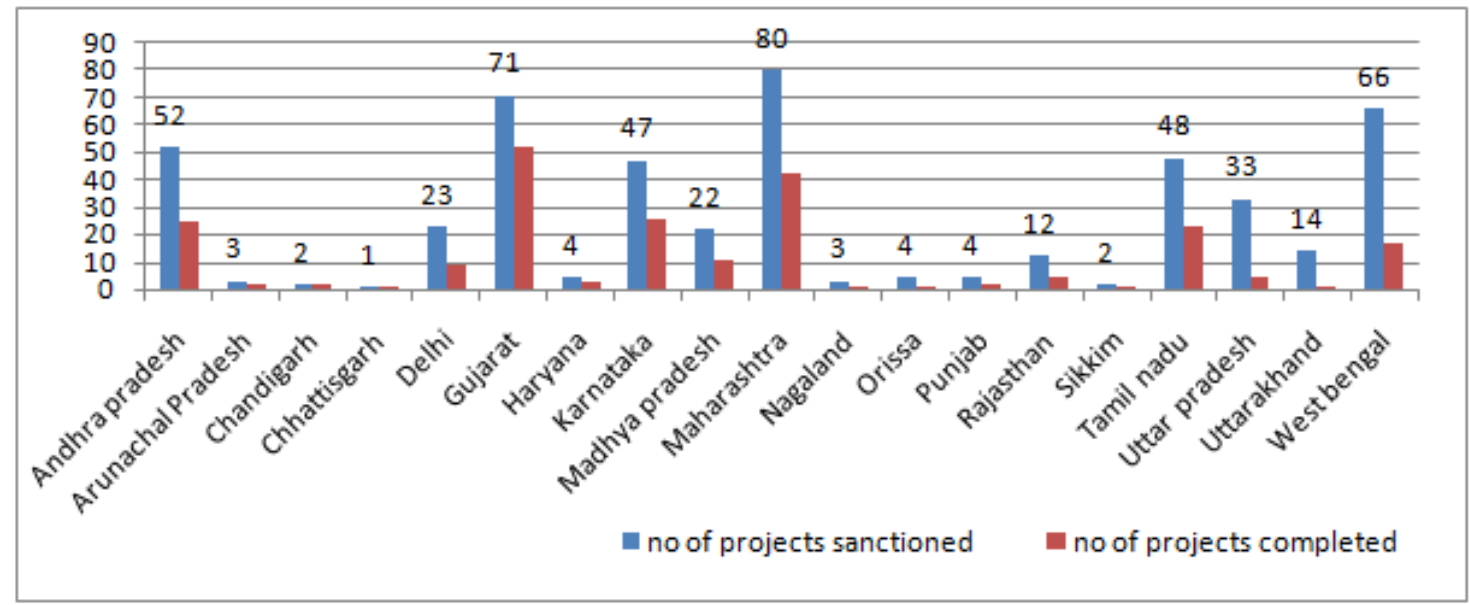

Above table shows us the number of sanctioned projects under JNNURM for each state and status of completion as on $29^{\text {th }}$ April 2014. Maharashtra was sanctioned with 80 projects out of which 42 were completed. Gujarat has been the best performer under the policy as it completed 52 of its projects out of 71 which is more than any other state whereas West Bengal was a most poor performer, only 17 projects were completed out of 66 sanctioned projects that is why its indicator PCA value is also insignificant. (Annexure 1.2).

\section{Conclusion And Recommendations}

In view of conflicting claims an attempt is made here to analyze rate and pattern of urbanization and their implication for accessing urban resources and overall economic growth. Urbanisation in India has always been subjected to criticism. The validity of the urbanisation portrayed by data has been the most prominent of all. The exponential increase in the number of Census Towns in India over the past decade has a major stake in the inflated urbanisation figures of India. The question whether the criterion ascertained for determining CTs in India, is it justifiable or not, is still unanswered. A comparison of the 2001 Census and the 2011 census brings the fact to light that most newly created CTs in India actually had satisfied the specified criterion to be a CT in the previous census period itself. This leaves behind an umpteen number of unanswered questions. The controversy over this, by a great extent, is being derogated by the debate over the validity of the criterion for determining a CT. The deficiencies of the criterion prescribed are to a great extent capsizing the government schemes and plans intended for up-lifting our cities. It is also evident that the increase in the number of CTs over the past one decade has seldom contributed towards the increase in urbanisation in real terms. This has been the most hazardous legacy of the CT determination criterion specified by the Indian authorities. The most dismal fact that one understands from this is that the CTs we have are not actually urbanised. Despite being ascertained as CTs, most of the CTs in India are still falling within the administrative framework of rural local bodies, hence being deprived of all governmental benefits that an urban area should receive. This fact has been 
dangling over the urbanisation dreams of this glorious as a dagger suspended on a string. The major solution that this study would like to recommend for this problem at hand is to redefine the criterion for determining a CT in the first place, and then to reconcile the repercussions of previous CT determination, provide necessary aid to the newly formed CTs on an emergency basis.

Another major finding of this study is that $65-70 \%$ of total urbanisation in India has been concentrated on the Class I cities in India due to the excessive migration into these cities from rural areas in search of a better life. This colossal population pressure that befalls our cities have multi-faceted consequences, the major one being the variety of associated crises that are brought about in these cities regarding providing for the basic needs of the population and many more. Moreover, the attention of our officials had been deviated to address the upcoming issues in the existing cities, from a more open goal of equally distributed urbanisation in India. Thus, in this modern day world, we see a lot of regional disparities when it comes to the urbanisation scenario of India. The humble solution that this study endeavours to provide for the issue of regionally impaired urbanisation in India is by providing urban facilities in rural India. Be it from the basic things like that of sewage to modern transport facilities. This is one factor that can prepare the ground for the rise of new cities and towns in India.

Yet another important factor that this study attempted to understand is the gap between actual urbanisation and the increase in number of cities over the past 60 years in India. Though we observe an increase in number of cities, we do not find an increase in overall urbanisation in such a level that could justify the increase in the number of cities. The study finds out that such a disparity is observed due to the massive population sheltered by the existing Class I cities in India makes the population of the newly formed cities look miniscule. Thus, the population of the newly formed cities are just marginal in comparison.

These criteria have, however, been described as vague and conservative on several bases:

1) Though the number of places with more than 5,000 populations is defined as 'urban' and there are 12,000 such places in India but the census recognizes only 3,245 places as urban.

2) The density of population that qualifies a place as urban is unrealistically low.

3) A place with more than 75 per cent of male working population engaged in non-agricultural activities is to be recognized as urban but according to 1981 and 1991 censuses, at least 25 per cent towns have agriculture as the dominant activity.

4) Female workers are excluded from working population. On this basis, 'urban community' is defined as 'a community characterized by a large heterogeneous population, predominance of nonagricultural occupations, complex division of labor, a high degree of specialization in work, dependence on formal social controls, and a formalized system of local government'.

The findings and the recommendations provided by this study, we believe, is the most feasible solution for the issue of impaired urbanisation pattern found in India. The way out for realising the urbanisation dreams of this great nation is not impossible, given the untapped potential of this country. But it is high time to realise that it is not an easy task. There should be adequate amount of planning that should go into the efforts we put to solve the issue at hand, moreover, a vision for sustained growth of urbanisation should fuel the aspirations.

\section{Acknowledgment}

I wish to express my sincere gratitude to National Institute of Urban Affairs for giving me opportunity to write this paper. I would also like to place on record my sincere thanks to Dr. Debolina Kundu, Associate Professor at NIUA for taking special interest in the project and providing valuable inputs in finalizing the paper.

Ms. Pragya Sharma provided holistic support and academic guidance to the paper, her interest in the project resulted in its successful completion I am grateful to her. I would also like to thank Dr Arpita Banerjee whose strong interest in the subject was responsible for undertaking of this study by me; I would also like to thank her for her patience and guiding me in every step of the project to make it a successful one. I would like to place on sincere thanks to Mr. T.C Sharma for providing with all data whenever I required and giving his valuable insights on the topic, his experience in the field has helped me at various stages of the study.

A special thanks goes to Mrs. Indu Senan (NIUA) and Mrs Sangeeta Vijh (NIUA) for providing technical support to the project from the beginning of the project.

At last I would like to thank my parents for always standing by my side and encouraging me in whatever task I do.

\section{References}

[2]. Census of India Urban development statistics. 
[3]. Census report 2011

[4]. Press notes on poverty estimates 2011 and 2001

[5]. Bhagat R.B (2006): RURAL-URBAN CLASSIFICATION AND MUNICIPAL GOVERNANCE IN INDIA

[6]. Growth of urbanization (chapter 2):Working Paper

[7]. Bhagat R.B (2008) Emerging pattern of urbanizing India

[8]. Kundu.A(2006): Trends and patterns of urbanization and their economic implications . India infrastructure report 2006.

[9]. Kundu.A (1992): Urban Development and urban research in India.

[10]. www.jnnurm.nic.in

[11]. www.planningcommission.nic.in

[12]. Statistics regarding trends of Urbanization in India by Smriti Chand. Working paper (2012)

[13]. Kundu. A, S Bagchi and D Kundu (1999): 'Regional distribution of infrastructure and basic amenities in urban India; Economic and political Weekly.

[14]. "Mapping the adverse sex ratio in India" Census 2011: Report

[15]. www.water.org

\section{ANNEXURES:}

1.1 Removed and new introduced UA in 2011

\begin{tabular}{|c|c|}
\hline New UA IN 2011 & Removed UA in 2011 \\
\hline Ghaziabad UA & Deoghar UA \\
\hline Chandigarh UA & Chidambaram UA \\
\hline Siliguri UA & Devarshola UA \\
\hline Gorakhpur UA & Chakradharpur UA \\
\hline Guntur UA & Visakhapatnam UA \\
\hline Durgapur UA & Ujjain UA \\
\hline Malegaon UA & Cuddapah UA \\
\hline Udaipur UA & Bijapur UA \\
\hline Kayamkulam UA & Junagadh UA \\
\hline Muzaffarpur UA & Vasai UA \\
\hline Korba UA & Guruvayoor UA \\
\hline Rampur UA & Bahadurgarh UA \\
\hline Barddhaman UA & Arcot UA \\
\hline Kadapa UA & Vadakara UA \\
\hline Darbhanga UA & Thanesar UA \\
\hline Dindigul UA & Mandsaur UA \\
\hline Thanjavur UA & Birnagar UA \\
\hline Santipur UA & Motihari UA \\
\hline Sambalpur UA & Begusarai UA \\
\hline Ranipet UA & Bhavani UA (Distts $09 \& 10$ ) \\
\hline Dankuni UA & Sawai Madhopur UA \\
\hline Mirzapur-cum-Vindhyachal UA & Coonoor UA \\
\hline Ottappalam UA & Kodungallur UA \\
\hline Bulandshahar UA & Chirmiri UA \\
\hline Udhagamandalam UA & Shrirampur UA \\
\hline Hosur UA & Tiruchendur UA \\
\hline Proddatur UA & Betul UA \\
\hline Chapra UA & Sirsi UA \\
\hline Hardoi UA & Shajapur UA \\
\hline Kumarapalayam UA & Rajgarh UA \\
\hline Orai UA & Khurai UA \\
\hline Sitapur UA & Khetri UA \\
\hline Modinagar UA & Mallasamudram UA (Distts 08 \& 09) \\
\hline S.A.S. Nagar UA & Wadi UA \\
\hline Chittoor UA & Sabalgarh UA \\
\hline Jalpaiguri UA & Nawanshahr UA \\
\hline Pilibhit UA & Sasni UA \\
\hline \multicolumn{2}{|l|}{ Bettiah (UA) } \\
\hline \multicolumn{2}{|l|}{ Rudrapur UA } \\
\hline \multicolumn{2}{|l|}{ Satara UA } \\
\hline \multicolumn{2}{|l|}{ Giridih UA } \\
\hline \multicolumn{2}{|l|}{ Basirhat UA } \\
\hline \multicolumn{2}{|l|}{ Khurja UA } \\
\hline \multicolumn{2}{|l|}{ Palwal UA } \\
\hline \multicolumn{2}{|l|}{ Etah UA } \\
\hline \multicolumn{2}{|l|}{ Bhadrak UA } \\
\hline \multicolumn{2}{|l|}{ Changanassery UA } \\
\hline \multicolumn{2}{|l|}{ Puruliya UA } \\
\hline \multicolumn{2}{|l|}{ Jangipur UA } \\
\hline \multicolumn{2}{|l|}{ Medninagar UA } \\
\hline \multicolumn{2}{|l|}{ Narasaraopet UA } \\
\hline \multicolumn{2}{|l|}{ Azamgarh UA } \\
\hline Sultanpur UA & \\
\hline
\end{tabular}


Urbanomics in India (Detailed analysis of trends and patterns of urbanization in India)

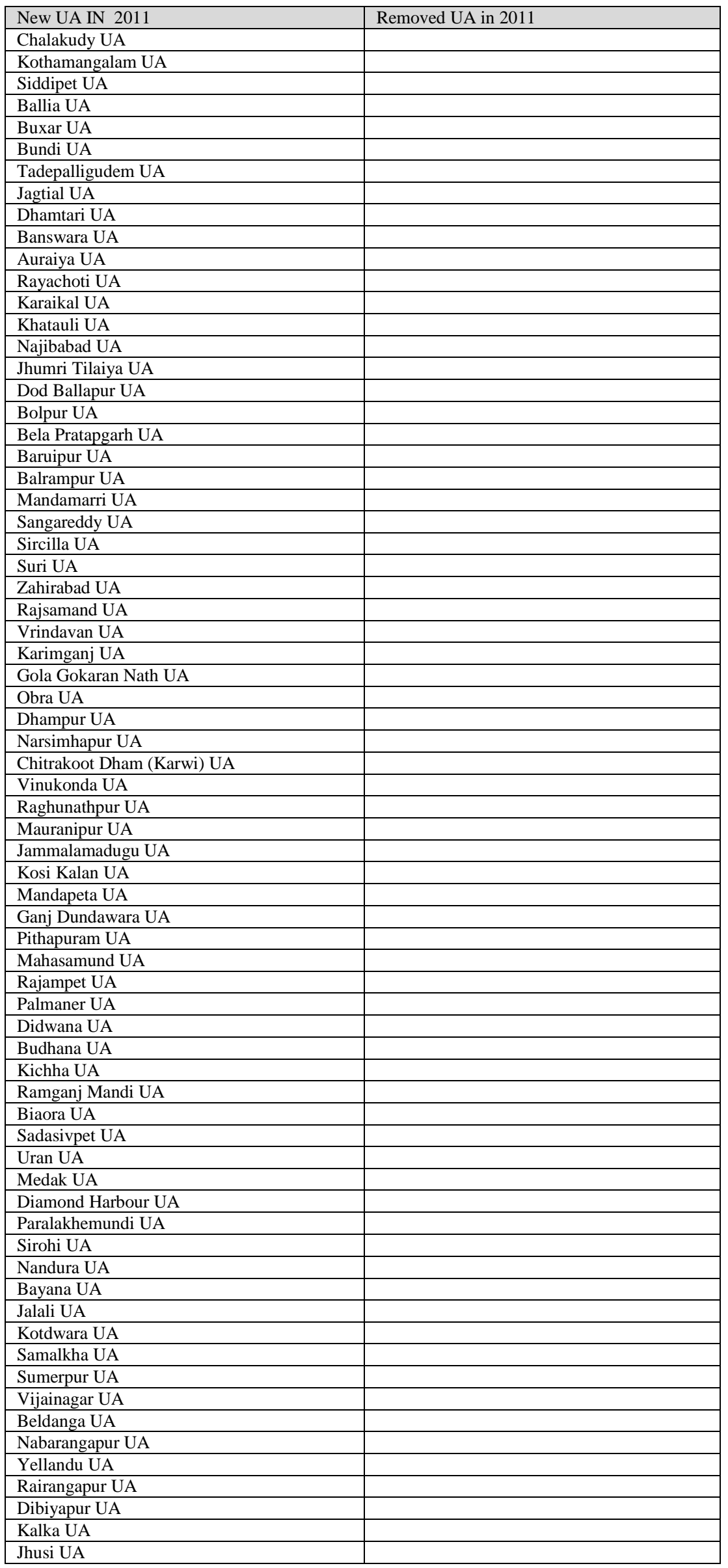


Urbanomics in India (Detailed analysis of trends and patterns of urbanization in India)

\begin{tabular}{|l|l|}
\hline New UA IN 2011 & Removed UA in 2011 \\
\hline Pundri UA & \\
\hline Pukhrayan UA & \\
\hline Dharmsala UA & \\
\hline Tulsipur UA & \\
\hline Baddi UA & \\
\hline Jhalda UA & \\
\hline Gotegaon UA & \\
\hline Sheoganj UA & \\
\hline Tufanganj UA & \\
\hline Mungaoli UA & \\
\hline Nainpur UA & \\
\hline North Guwahati UA & \\
\hline
\end{tabular}

1.2 State wise allocation in JNNURM and its share

\begin{tabular}{|c|c|c|}
\hline State & Total Amount (in Rs lakh) & $\%$ share \\
\hline Andaman and nicobar & 558.13 & 0.006087 \\
\hline Andhra Pradesh & 729239.2 & 7.952502 \\
\hline Arunachal Pradesh & 41631.04 & 0.453995 \\
\hline Bihar & 66717.15 & 0.727564 \\
\hline Chandigarh & 189155.3 & 2.062777 \\
\hline Chhattisgarh & 5698.6 & 0.062144 \\
\hline Daman and Diu & 85206.66 & 0.929196 \\
\hline Dadra Nagar and Haveli & 942.37 & 0.010277 \\
\hline Delhi & 1864.73 & 0.020335 \\
\hline Goa & 664955 & 7.251469 \\
\hline Gujarat & 10359.08 & 0.112968 \\
\hline Haryana & 667767.4 & 7.282139 \\
\hline Himachal Pradesh & 99684.92 & 1.087084 \\
\hline Jharkhand & 44313.77 & 0.483251 \\
\hline Jammu and Kashmir & 122576 & 1.336716 \\
\hline Karnataka & 128558.1 & 1.401952 \\
\hline Kerala & 596162.8 & 6.501276 \\
\hline Maharashtra & 1802041 & 19.54527 \\
\hline Manipur & 151719.1 & 1.654 \\
\hline Meghalaya & 30647.85 & 0.334221 \\
\hline Mizoram & 23228.98 & 0.253317 \\
\hline Madhya Pradesh & 597522.5 & 6.516104 \\
\hline Nagaland & 14326.34 & 0.156232 \\
\hline Orissa & 134430.2 & 1.465989 \\
\hline Pondicherry & 16823.89 & 0.183468 \\
\hline Punjab & 40401.9 & 0.440591 \\
\hline Rajasthan & 178219.8 & 1.943523 \\
\hline Sikkim & 358144.6 & 3.90564 \\
\hline Tamil Nadu & 778582.3 & 8.490598 \\
\hline Tripura & 13646.49 & 0.148818 \\
\hline Uttarakhand & 25863.81 & 0.28205 \\
\hline Uttar Pradesh & 70263.3 & 0.766236 \\
\hline West Bengal & 703578.7 & 7.672669 \\
\hline INDIA & 9169935 & \\
\hline
\end{tabular}

\subsection{PCA: Social Indicators}

\begin{tabular}{|l|l|}
\hline STATE & PCA Value: \\
\hline Jammu and Kashmir & -1.74 \\
\hline Himachal Pradesh & 0.13 \\
\hline Punjab & -1.25 \\
\hline Chandigarh & -1.04 \\
\hline Uttarakhand & -0.56 \\
\hline Haryana & -1.561 \\
\hline NCT of Delhi & -0.9033 \\
\hline Rajasthan & -1.04 \\
\hline UP & -1.28 \\
\hline Bihar & -0.78 \\
\hline Sikkim & 0.147 \\
\hline Arunachal Pradesh & 0.37 \\
\hline Nagaland & 0.98 \\
\hline Manipur & 0.64 \\
\hline Mizoram & 1.86 \\
\hline Tripura & 1.12 \\
\hline Meghalaya & 1.13 \\
\hline
\end{tabular}


Urbanomics in India (Detailed analysis of trends and patterns of urbanization in India)

\begin{tabular}{|l|l|}
\hline Assam & 0.64 \\
\hline West Bengal & 0.38 \\
\hline Jharkhand & -0.3087 \\
\hline Orissa & 0.1686 \\
\hline Chhattisgarh & 0.409 \\
\hline MP & -0.406 \\
\hline Gujarat & -0.8006 \\
\hline Daman \& Diu & -1.718 \\
\hline Dadra Nagar and Haveli & -1.036 \\
\hline Maharashtra & 0.2515 \\
\hline Andhra Pradesh & 0.3635 \\
\hline Karnataka & 0.5459 \\
\hline Goa & 0.722 \\
\hline Lakshadweep & 0.45 \\
\hline Kerala & 2.0282 \\
\hline Tamil Nadu & 0.81 \\
\hline Pondicherry & 1.47 \\
\hline A\&I Islands & 0.338 \\
\hline PCA run accordingly) &
\end{tabular}

Source: Census of India (PCA run accordingly)

\section{4 : PCA: Economic Indicators}

\begin{tabular}{|c|c|}
\hline STATE & PCA Value: \\
\hline Jammu and Kashmir & -0.04 \\
\hline Himachal Pradesh & 0.56 \\
\hline Punjab & 0.48 \\
\hline Chandigarh & 0.69 \\
\hline Uttarakhand & 0.34 \\
\hline Haryana & 0.277 \\
\hline NCT of Delhi & 1.46 \\
\hline Rajasthan & -0.403 \\
\hline UP & -1.69 \\
\hline Bihar & -2.19 \\
\hline Sikkim & 0.138 \\
\hline Arunachal Pradesh & -0.22 \\
\hline Nagaland & -0.166 \\
\hline Manipur & -1.59 \\
\hline Mizoram & 0.60123 \\
\hline Tripura & -0.5407 \\
\hline Meghalaya & 0.879 \\
\hline Assam & -1.002 \\
\hline West Bengal & -0.32 \\
\hline Jharkhand & -1.17 \\
\hline Orissa & -1.12 \\
\hline Chhattisgarh & -1.18 \\
\hline MP & -1.044 \\
\hline Gujarat & 0.239 \\
\hline Daman \& Diu & $\mathrm{Na}$ \\
\hline Dadra Nagar and Haveli & $\mathrm{Na}$ \\
\hline Maharashtra & 1.25 \\
\hline Andhra Pradesh & 0.42 \\
\hline Karnataka & -0.15 \\
\hline Goa & 2.18 \\
\hline Lakshadweep & $\mathrm{Na}$ \\
\hline Kerala & 0.106 \\
\hline Tamil Nadu & 0.36 \\
\hline Pondicherry & 1.519 \\
\hline A\&I Islands & 1.104 \\
\hline
\end{tabular}

Note*( Due to non availability of data 3 ut's have been excluded)

\section{5: PCA: Infrastructure and Housing}

\begin{tabular}{|l|l|}
\hline STATE & PCA Value: \\
\hline Jammu and Kashmir & 0.68 \\
\hline Himachal Pradesh & 1.297 \\
\hline Punjab & 0.71 \\
\hline Chandigarh & 1.14 \\
\hline Uttarakhand & 0.91 \\
\hline Haryana & 0.543 \\
\hline NCT of Delhi & 0.94 \\
\hline Rajasthan & -0.16 \\
\hline
\end{tabular}


Urbanomics in India (Detailed analysis of trends and patterns of urbanization in India)

\begin{tabular}{|l|l|}
\hline UP & -0.93 \\
\hline Bihar & -2.72 \\
\hline Sikkim & 0.99 \\
\hline Arunachal Pradesh & 0.081 \\
\hline Nagaland & 0.12 \\
\hline Manipur & -1.94 \\
\hline Mizoram & 0.599 \\
\hline Tripura & -0.49 \\
\hline Meghalaya & 0.09 \\
\hline Assam & -0.405 \\
\hline West Bengal & -1.011 \\
\hline Jharkhand & -1.2424 \\
\hline Orissa & -1.789 \\
\hline Chhattisgarh & -1.722 \\
\hline MP & -0.767 \\
\hline Gujarat & 0.518 \\
\hline Daman \& Diu & 0.00879 \\
\hline Dadra Nagar and Haveli & 0.297 \\
\hline Maharashtra & 0.266 \\
\hline Andhra Pradesh & -0.144 \\
\hline Karnataka & 0.412 \\
\hline Goa & 1.004 \\
\hline Lashadweep & 1.33 \\
\hline Kerala & 0.846 \\
\hline Tamil Nadu & -0.449 \\
\hline Pondicherry & 0.052 \\
\hline A\&I Islands & 0.633 \\
\hline 211 &
\end{tabular}

Source: Census of India 2011"

A \& Islands

0.633 